\section{Principles of Intentional Mentoring}

\section{Margaret Werner-Washburne*}

University of New Mexico Initiative to Maximize Student Development, Biology Department, University of New Mexico, Albuquerque, NM 87131

M entoring is a word with many meanings. Mentoring (Livingstone and Naismith, 2018), coaching (Williams et al., 2017), sponsoring (Ashkenas, 2015) ... all these words are used sometimes interchangeably and without much care. In my experience, the common goal for most mentors, coaches, or sponsors is to see the people we work with develop into strong, creative leaders and team players. My colleagues and I have developed and implemented a principle-based student-mentoring program over the past decade. For freshman, sophomore, and transfer student participants, the result is an $80 \%$ retention and graduation rate ( $n=97$ over 6 years) and a 40-60\% increase in retention and graduation of Native American students at the University of New Mexico. For our pre-PhD participants, $\sim 70 \%$ of the almost 300 students from underrepresented groups enrolled in graduate or professional schools, with $\sim 95 \%$ completing their PhDs. About $75 \%$ of all of our former students are working in areas related to their education. When people see these results, they often ask me what we do that makes this program so effective. There is a long answer to this question, which will be most of this article, but there is also a short answer: as I have grown and learned, so has the program.

My journey with mentorship began with 20 years as a professor and traditional research mentor. In this role, I focused on helping my students learn how to think like scientists. We worked together on developing hypotheses, designing experiments, and troubleshooting. The goal then was to prepare my students to be important contributors to scientific discussions and discoveries. The success of these students has been a great reward, but being a research mentor for the students in your research group (Barres, 2013) is very different from other types of mentoring.

Fifteen years ago, I assumed a new role as the principal investigator of the National Institutes of Health-funded Initiative for Maximizing Student Development (IMSD) program, supporting undergraduate and graduate students from underrepresented groups to do research. Because the students were in labs other than mine, I was not their research mentor and suddenly I had to rethink what mentoring meant. From this new perspective, I discovered the students needed and could benefit from another kind of mentoring. I also learned that there were theories and relatively complex structures for evaluating what I was trying to do intuitively (Yeager and Walton, 2011). At that time, I didn't know what to call it. Years later, I learned that social scientists described two types of mentorship support: instrumental and psychosocial (Eby et al., 2012). The more traditional-quality research mentorship provides instrumental support, or "how-to" or career-related advice, including giving students access to research experiences and supporting them through professional development. In contrast, psychosocial support involves facilitating their emotional and personal development (Flaxman et al., 1988; Nakkula and Harris, 2005). The latter type of support is the basis of the principle-based program I have developed.

In doing this work, I bring my culture (as a Hispanic woman), a wealth of life experiences (including 10 years in and after college, discovering my path through traveling in the Americas, Samoa, New Zealand, and Hawaii), and a strong desire to help students live lives of authenticity and integrity. As my colleagues and I developed the principle-based IMSD mentorship program, we thought hard about what we wanted
Kenneth Gibbs, Monitoring Editor Submitted May 14, 2018; Accepted May 23, 2018 CBE Life Sci Educ September 1, 2018 17:es8 DOI:10.1187/cbe.18-05-0074

*Address correspondence to: Margaret Werner-Washburne (maggieww@unm.edu) (c) 2018 M. Werner-Washburne. CBE-Life Sciences Education (c) 2018 The American Society for Cell Biology. This article is distributed by The American Society for Cell Biology under license from the author(s). It is available to the public under an Attribution-Noncommercial-Share Alike 3.0 Unported Creative Commons License (http://creativecommons.org/licenses/ by-nc-sa/3.0)

"ASCB®" and "The American Society for Cell Biology ${ }^{\circledR}$ " are registered trademarks of The American Society for Cell Biology. 
TABLE 1. Current and former participant views of IMSD principles ${ }^{a}$

\begin{tabular}{|c|c|c|c|c|c|}
\hline \multirow[b]{2}{*}{ Question } & \multicolumn{5}{|c|}{ Percent $(N)$} \\
\hline & Very helpful & Helpful & Neutral & Unhelpful & Very unhelpful \\
\hline $\begin{array}{l}\text { 1. Knowing your heart has been helpful } \\
\text { to me }\end{array}$ & $60.18(68)$ & $24.78(28)$ & $5.31(6)$ & $3.54(4)$ & $4.42(5)$ \\
\hline $\begin{array}{l}\text { 2. Looking for the positive has been helpful } \\
\text { to me }\end{array}$ & $62.83(71)$ & $26.55(30)$ & $4.42(5)$ & $1.77(2)$ & $4.42(5)$ \\
\hline $\begin{array}{l}\text { 3. Embracing who you are and bringing it } \\
\text { to the table has been helpful to me }\end{array}$ & $62.83(71)$ & $18.58(21)$ & $11.50(13)$ & $1.77(2)$ & $4.42(5)$ \\
\hline 4. Finish well has been helpful to me & $54.87(62)$ & 30.97 (35) & $7.96(9)$ & $1.77(2)$ & $2.65(3)$ \\
\hline
\end{tabular}

aSurveys were sent to $\sim 310$ former participants by email in July of 2017 . The response $(N=113)$ rate was $36 \%$.

the students to gain from their time with us. Our goals were to graduate students who were resilient and who possessed the tools they needed to make choices for their futures: emotional intelligence, security in who they were, and the creativity and capability to reframe experiences and perspectives. With this in mind, we developed four principles around which we centered our student development activities:

1. Know your heart.

2. Look for the positive or the blessing in everything.

3. Embrace who you are and bring it to the table.

4. Finish well.

These principles continue to be valuable to us and our students, years after leaving the program. We recently completed a survey of current and former IMSD students and found that well over $80 \%$ of the participants distributed through all years of the program felt the principles were useful or very useful (Table 1).

\section{PRINCIPLE 1. KNOW YOUR HEART}

I knew the most important gift I could give to a young person would be permission and encouragement to know what it was they loved. Often in life we are so busy reacting that we don't pay attention to what we are choosing. Before joining our program, many of our students had not thought about whether they loved what they were doing in school. They simply did it because it was what their parents or grandparents said they should be doing. Others just wanted a job that would allow them to support their families. After spending time to hear their hearts, they discover the joy of being in charge of their education and life and of discovering their own creativity and intelligence.

Knowing our heart is a lifelong activity. The first step is to examine our values - keeping our values and priorities in mind is key to having a fairly constant conversation with our heart. The second step is to list all the things that, when they come to mind, make us happy. It can be food, a love interest, a movie or video game, something we learned in class, things we like to do, and so on. This list is the first part of the journal I encourage our students to write. As we discover more things that we love, we begin to see what it is that our heart might be saying to us. I've found that knowing our heart frees us to move forward without fear and is a key to self-motivation.

Mentors who have experienced the terror of not knowing their hearts can empathize. As an undergraduate, on a full-tuition scholarship at Stanford, I was a terrified, insecure mess. After graduation with a BA in English and a newfound desire to meet the writer Pablo Neruda, I traveled to Mexico and beyond. I discovered how people used what was around them to dye their clothes and heal themselves, and my curiosity and the reward of learning replaced my insecurity. By the time I got to graduate school in Botany, my passion (ganas) for learning was so great, I was incredibly motivated, wanting to learn everything I could. In fact, it scared some professors who weren't used to a student in a huge physics class coming to office hours and being so excited to ask questions. When I came to New Mexico, I realized that I was able to see great opportunity where others couldn't. Knowing my heart gave me vision and peace in my choices, and I wanted to share that with our students.

\section{PRINCIPLE 2. LOOK FOR THE POSITIVE OR THE BLESSING IN EVERYTHING}

This is the recognition, like the yin and yang of Eastern philosophy, that nothing is all good or all bad. It is not about ignoring difficulties in life. It is about taking the time to think deeply about an event we remember as negative to see more positives than we imagined. Looking for the positive is not to say that anger and grief have no place or should be discounted. Rather, even in horrible situations, it is possible to find some good, balancing elements, and with practice this becomes easier and liberates us.

In the purest sense, this principle is about survival and leadership, empowering us to choose our response to an event. For example, when someone is unkind, maybe even showing overt racism, we have two immediate positives. First, we are not that person, and second, we are not married to that person. Typically, the students laugh at this thought. The laughter is incredibly important. It gives them a millisecond to realize that we can choose how we are going to respond; that no one can make us respond in a particular way. None of us has to get into the mud with people like that, and they have to go home and live with themselves. Because we are a strong team together, if the bad behavior continues, we can address it together, but it's important to remember we have the right and, in most situations, the ability to walk away.

This principle helps us develop resilience because it prepares us to deal with difficulty. It requires learning to be creative and reframe our experiences productively, so we can see them from different perspectives. It allows us to see failures and challenges as teachers, so we are able to move forward with confidence and without fear. For most of us, even if we recognize its importance, looking for positives is not something that we do automatically. What we see as bad experiences can stay with us and can hold us back. We need to immerse ourselves in the 
event and look around for the positives, so our memory becomes more complex. This principle is easy to describe but difficult to make automatic in practice. For this reason, it helps to have people around us who also practice this principle and who are unafraid to remind us when we have forgotten it.

\section{PRINCIPLE 3. EMBRACE WHO YOU ARE AND BRING IT TO THE TABLE}

This is the diversity principle. It is about recognizing our unique personal and family narratives and how important they both are for our self-knowledge and to our ability to be part of and contribute to our community. It is also about reframing, finding wisdom and strength in who we are, and encouraging everyone we interact with to do the same. It is the principle that affirms the value of both our individual experience and our shared humanity.

Embracing who we are and where we come from deepens and strengthens us. First, when we come into a new situation, one in which we may not have status, remembering the physical reality of the DNA from our ancestors within us makes us feel less alone and gives us a sense of depth and value. Imposter syndrome can happen in these situations - the feeling that once people know us, they'll know we don't belong or can't measure up (Persky, 2018). That is when we wrap ourselves in this wonderful blanket of our ancestors, who made sacrifices and whose joys and sorrows, victories and defeats made our lives possible, and who are with us as we speak.

Principle 3 can help us to see our potential by revisiting our personal narrative. I love watching that moment when mentees realize that their narratives are interesting and valuable. We may think our path from birth to today is uninteresting, or we may have things in our past that we feel bad about and that hold us back or make us feel like we don't have anything to offer. Identifying these events and examining them with principle 2 in mind (looking for the positive, increasing the complexity of the memory) lets us see that early mistakes that we may feel have branded us for life are, in fact, valuable teachers. The sum of these experiences and our resulting choices have made us who we are. I often describe the most challenging childhoods as unrecognized PhDs in life.

This principle is critical to fostering diversity. Our goal in diversity is not to bring together a table of people from different races and backgrounds who don't contribute to the conversation. Instead, it's about having groups with varied backgrounds and narratives use their individual perspectives to generate multiple solutions to hard problems (Page, 2007). We have massive common ground and wonderful differences. Finding ways to hear and appreciate one another's stories facilitates team building and problem solving. It gets us all past the idea that we cannot talk to each other or that we are completely separated by culture.

\section{PRINCIPLE 4. FINISH WELL (OR STICK THE LANDING)}

This principle is meant to bring the student full circle. In Daniel Kahneman's book Thinking Fast and Slow (Kahneman, 2011), he mentions work that demonstrates that humans remember a high or low point and the last interaction (i.e., the landing). So, students-and most of us-need to remember, when we finish something (e.g., a class, a difficult day, or a long-term interaction), we should look around us, thank all those who have helped us, and make sure that we are leaving a situation better for our having been there.

Principle 4 brings us full circle and makes us look outward again, acknowledging and thanking those who helped us along the journey. All of us, young and old, can forget to look back, to wrap things up. This principle, I must confess, is born out of my regrets for times when I didn't finish well. For example, when I was at Stanford, I had imposter syndrome for 4 years. There were so many wealthy students and everyone seemed so confident. I never felt as though I found my niche. When I graduated (a quarter before my class), I left without saying good-bye to anyone. I lost almost all of my friends, but because my self-confidence was so low, I couldn't believe that anyone would care.

As I've grown in my career, I have realized how critically important relationships are to career success. So, principle 4 is to remind us all that we have no warranty on this life and that we are successful not only because of ourselves and our efforts, but because of other people who have been allies and teachers and friends. It is a reminder to let them know. I wish I could go back and thank my friends for helping me at Stanford. Principle 4 is about ensuring you are aware of your environment and community and, especially, that you show gratitude for your relationships.

\section{CONCLUSION}

Through these four principles_-knowing your heart, reframing experiences, embracing who you are, and finishing well-our approach has never been about "fixing" a student (Gazley et al., 2014), but about equipping students with the tools for resilience, and success in science and, more importantly, in life. In fact, many of my students and colleagues use the principles in talking with their friends and families. I have found that attending to various psychosocial factors not only develops stronger, happier people, it provides a foundation for the research success of students from all backgrounds-especially minority and first-generation students. Perhaps, by attending to more of these factors, the scientific community could better identify and cultivate the next generation of scientists, whoever they are and whatever group they come from.

\section{ACKNOWLEDGMENTS}

A great thank you to Lupe Atencio, Steve Phillips, and Nancy Hurtado-Ziola for your support, conversations, efforts, and inspiration. To Danielle Duran, Maria Beatriz Velez, Roberto Ibarra, and Billie Ulibarri for evaluating our program and enlightening discussions. And to the students, past and present, who are the river that runs through my life.

\section{REFERENCES}

Ashkenas, R. (2015, May). How to be an effective executive sponsor. Harvard Business Review.

Barres, B. (2013). How to pick a graduate advisor. Neuron, 80(2), 275-279 doi: 10.1016/j.neuron.2013.10.005

Eby, L. T. T., Allen, T. D., Hoffman, B. J., Baranik, L. E., Sauer, J. B., Baldwin, S ... Evans, S. C. (2012). An interdisciplinary meta-analysis of the potential antecedents, correlates, and consequences of protégé perceptions of mentoring. Psychological Bulletin, 139(2), 441-476. doi: 10.1037/ a0029279

Flaxman, E., Ascher, C., \& Harrington, C. (1988). Youth mentoring: Programs and practices. Urban Diversity Series No. 97. New York: ERIC Clearinghouse on Urban Education, Teachers College, Columbia University. Retrieved from https://files.eric.ed.gov/fulltext/ED308257.pdf 
Gazley, J. L., Remich, R., Naffziger-Hirsch, M. E., Keller, J., Campbell, P. B., \& McGee, R. (2014). Beyond preparation: Identity, cultural capital, and readiness for graduate school in the biomedical sciences. Journal of Research in Science Teaching, 51(8), 1021-1048. doi: 10.1002/tea.21164

Kahneman, D. (2011). Thinking fast and slow. New York: Farrar, Straus \& Giroux.

Livingstone, N., \& Naismith, N. (2018). Faculty and undergraduate student perceptions of an integrated mentoring approach. Active Learning in Higher Education, 19(1), 77-91. doi: 10.1177/1469787417723233

Nakkula, M. J., \& Harris, J. T. (2005). Assessment of mentoring relationships. In DuBois, D. L., \& Karcher, M. J. (Eds.), Handbook of youth mentoring (pp. 100-117). Thousand Oaks, CA: Sage.
Page, S. E. (2007). The difference: How the power of diversity creates better groups, firms, schools, and societies. Princeton, NJ: Princeton University Press.

Persky, A. M. (2018). Intellectual self-doubt and how to get out of it. American Journal of Pharmaceutical Education, 82(2), 6990.

Williams, S. N., Thakore, B. K., \& McGee, R. (2017). Providing social support for underrepresented racial and ethnic minority $\mathrm{PhD}$ students in the biomedical sciences: A career coaching model. CBE-Life Sciences Education, 16(4). doi: 10.1187/cbe.17-01-0021

Yeager, D., \& Walton, G. M. (2011). Social-psychological interventions in education: They're not magic. Review of Educational Research, 81, 267301. 


\section{HIGHLIGHTS:}

This essay elucidates four universal principles that have been used in a psychosocial mentoring approach to help mentors and mentees to understand themselves, learn productive reframing, build their personal and family narratives, discover their paths forward, and make decisions that fit who they are, their values, and what they love. 